\title{
PENGEMBANGAN MEDIA PEMBELAJARAN VIDEO ANIMASI UNTUK MATA PELAJARAN MEKANIKA TEKNIK KELAS X DESAIN PEMODELAN DAN INFORMASI BANGUNAN DI SMK N 2 YOGYAKARTA
}

\author{
Tiara Titania ${ }^{1}$ dan Slamet Widodo ${ }^{2}$ \\ ${ }^{1,2}$ Pendidikan Teknik Sipil dan Perencanaan, FT, UNY \\ Email: titaniatiara@gmail.com
}

\begin{abstract}
ABSTRAK
Penelitian ini dilaksanakan untuk mengembangkan media pembelajaran animasi untuk mekanika teknik berdas arkan kurikulum SMK 2013 Revisi 2016 yang layak dan dapat menjadi alternatif sumber belajar sis wa. Penelitian initermasuk penelitian dan pengembangan atau Research and Development (R\&D) dengan model penelitian 4D (Define, Design, Development and Dis s eminate) dan disesuaikan dengan kebutuhan.Pengumpulan data menggunakan angket ahli dan ku is ioner didukung dengan kegiatan observasi. Angket ahlidiberikankepada ahli materi, ahli media dan angket kuisioner diberikan untuk pengguna (guru pengampu Mekanika TeknikSMK N 2 Yogyakarta). Hasil penelitian ini berupa media pembelajaran video animasi untuk mata pelajaran Mekanika Teknik dengan has il setiap tahap sebagai berikut:(1) Has il tahap define adalah analis is kebutuhan awalyaitu siswa belum mengetahui konsep dari pemodelan struktur, cara belajar setiap sis wa yang berbeda dan media yang digunakan kurang bervariasi. Analisis konsep menghasilkan konsep tampilan media secara umumdan analis is tugas menghasilkan penetapan kompetensidas aryang menyesuaikan dengan analis is kebutuhan awaluntuk kemudian dirumuskan tujuan pembelajarannya; (2) Hasil tahap design adalah susunan materi berdasarkan kompetensi das ar dan indikator yang telah ditetapkan. Has il akhir media berformat exe terdiri dari animasi,video dan teks; (3) Hasil tahap development berupa nilai dari validasi ahli dan calon pengguna sebagai berikut: a) penilaian ahli materi pada media pembelajaran animasi mekanika teknik mendapatkan skor 68 dan persentase $100 \%$ dan dinyatakan bahwa media sangat layak, b) penilaian ahli media pada animasi media pembelajaran mekanika teknik mendapatkan skor 84 dan pers entase 91,6\% dan dinyatakan bahwa media sangat layak, dan c) penilaian dari uji coba calon pengguna pada media pembelajaran video animasimekanika teknik mendapatkan rata-rata skor 39,5 dan persentase 76,3\% dan dinyatakan bahwa media layak digunakan.
\end{abstract}

Kata kunci: Animasi, Media pembelajaran, Mekanika teknik, SMK

\section{ABSTRACT}

The aim of this research is to develop video animation learning media of Engineering Mechanic subjects based on the SMK's curriculum at the 2013 academics year and revised at 2016thatiswelldevelopedandassessed to be properly implemented as an alternative learning media by subject-matter and learning mediaexpertand also by the potential users. This study applied a Research and Development $(R \& D)$ using $4 D(D e f i n e, D e s i g n$, Development, and Dissemination) research model. The data were collected using questionnairessupported with some relevant observations. The questionnaires were administered to subject matterandlearningmediaexperts, and users (teachers). The data were analyzed using descriptive-quantitative technique. The resultsofthisstudy can be concluded as follows. (1) The making ofproposed learning media started with defineprocesswhichwas finding the background of this study that is the students of $10^{\text {th }}$ grade cannot understand the basic conceptof structural modeling, each of them has a different way oflearning and the main problems arethelack oflearning media. Concept analysis results the general media display and task analysis results thecompetenciesthatadjust the needs analysis and then formulated the learning objectives; (2) The result ofdesignwassubject-mattersorting based on SMK curriculum and compiling media in the exe format consisting of animations, videos, audiosand texts; (3) The result ofdevelop stage was the assessment of Engineering Mechanic's AnimationLearningMedia which is justified to be very proper by subject-matter, learning media and potential users with detailsasfollow: a) justified as very proper by gaining score of 68 which is equal to $100 \%$ by the subject-matterexpert,b)classified as very proper based on total score of 84 which is equal with a percentage of $91,6 \%$ bythelearningmediaexperts, and c) average score of 39,5 that equal with 76,3\% and can be categorized as proper to be implemented by potential users.

Keywords: Animation, Engineering mechanics, Learning media, SMK 


\section{PENDAHULUAN}

Kemajuan dunia pendidikan merupakan salah satu tolak ukur untuk dapat memajukan suatu bangsa. Pendidikan pada saat ini diharapkan dapat meningkatkan inovasi dan kreativitas di bidang pemanfaatan teknologi dikarenakan perkembangan teknologi yang begitu pesat di era saat ini.

Sekolah Menengah Kejuruan (SMK) adalah salah satu bentuk lembaga pendidikan, khususnya bidang sekolah menengah atas yang berbasis kejuruan. Dalam Peraturan Pemerintah RI Tahun 1990 Nomor 29 tentang Pendidikan Menengah, disebutkan bahwa sekolah kejuruan merupakan sekolah yang khusus menyiapkan siswa terutama untuk dapat bekerja pada bidang tertentu dengan sikap profesional.

Berdasarkan proses pengamatan pembelajaran di SMK, guru masih menggunakan metode ceramah yang kurang melibatkan keaktifan siswa. Selain itu, media pembelajaran yang digunakan masih kurang memanfaatkan teknologi. Selanjutnya, Wasno (2009: 28) menyatakan bahwa model konvensional yang bersifat penyampaian informasi satu arah ini, kurang dapat mengakomodasi kecepatan belajar, kemampuan belajar dan konsentrasi belajar masing-masing siswa pada saat menerima penjelasan dari guru. Ia juga menambahkan bawah tidak adanya sumber informasi lain selain buku yang digunakan guru untuk menyampaikan informasi

Berdasarkan konsep pembelajaran tersebut, dalam menciptakan suasana yang dapat mendorong siswa untuk nyaman belajar, guru juga harus menggunakan media pembelajaran yang dapat menciptakan suasana dimana siswa dapat bertanya, mengamati, menemukan fakta dan konsep dengan cara berpikir dirinya sendiri. Menurut Widiana (2018: 263) salah satu usaha untuk meningkatkan aktivitas pembelajaran di sekolah, perlu dikembangkan kreativitas dan inovasi media pembelajaran dari guru agar siswa tertarik mengikuti pembelajaran.

Dalam proses pengamatan saat melakukan Praktik Lapangan Persekolahan (PLP) di SMK N 2 Yogyakarta, guru cenderung menggunakan media seperti powerpoint, papan tulis, wallchart dan media lain yang bersifat ada pada satu bidang saja.

Menurut siswa kelas X DPIB, masih ditemui banyak kebingungan terhadap pemodelan dari bentuk struktur bangunan nyata menjadi pemodelan struktur dalam bidang 2D atau dalam suatu bidang gambar. Dari uraian tersebut, guru pengampu mata pelajaran Mekanika Teknik merasa perlu adanya pembelajaran yang inovatif dikarenakan masih banyak siswa yang belum memahami bentuk nyata dari elemenelemen struktur yang ada di suatu pemodelan bangunan. Salah satu inovasi yang dapat dikembangkan adalah dengan memanfaatkan media pembelajaran berbasis komputer dengan berbagai macam software yang ada.

Inovasi ini sejalan dengan pendapat Sukoco, dkk (2014: 220) yang menyatakan bahwa media pembelajaran menempati posisi yang cukup penting sebagai salah satu komponen sistem pembelajaran. Komunikasi yang optimal tidak akan terjadi tanpa adanya media. Selain itu, media pembelajaran yang baik dapat menciptakan suasana belajar yang menyenangkan dan berkesan. Sukoco dkk (2014: 221) menambahkan media pembelajaran yang baik saat ini dapat dikembangkan dengan memanfaatkan teknologi mutakhir khususnya komputer, dari teknologi saat ini dapat diciptakan media yang bisa memvisualisakan materi dengan menarik.

Salah satu software yang digunakan dalam pembuatan media pembelajaran adalah adobe flash cs6. Supriyadi $(2016,39)$ menyatakan penggunaan software adobe flash cs6 dalam sarana komputer dapat menyeimbangkan kebutuhan waktu dan keperluan pemrosesan dari tugas-tugas tertentu, serta memungkinkan 


\section{Pengembangan Media Pembelajaran... (Tiara/ hal. 89-94)}

pengembangan pendekatan pembelajaran bervariasi. Software ini menyediakan berbagai macam fitur grafis dan pembuatan animasi dengan cara yang mudah untuk digunakan animator.

Berangkat dari latar belakang diatas, peneliti tertarik untuk melakukan pengembangan media dengan judul Pengembangan Media Pembelajaran Mekanika Teknik Berbasis Adobe Flash Player CS6 untuk siswa kelas X Bidang Keahlian Teknik Konstruksi dan Properti di SMK N 2 Yogyakarta.

\section{METODE}

Jenis penelitian ini termasuk penelitian pengembangan atau Research and Development $(R \& D)$ dengan menggunakan model penelitian 4D dari Thiagarajan. Tujuan dari penelitian ini adalah menghasilkan media pembelajaran yang baik dan layak berdasarkan pertimbangan para ahli. Para ahli terdiri dari ahli materi dan ahli media setelah dilakukan penilaian ahli baru dilakukan uji coba pengembangan pada calon pengguna yang terbatas pada guru.

Penelitian ini dilakukan di Jurusan Pendidikan Teknik Sipil dan Perencanaan, Fakultas Teknik UNY dan uji coba pengembangan pada SMKN 2. Yogyakarta di Jalan A.M Sangaji, Kota Yogyakarta, D.I. Yogyakarta.

Data dalam penelitian diperoleh dari para ahli yaitu dosen Pendidikan teknik sipil dan perencanaan dan guru SMKN di Provinsi D.I. Yogyakarta. Data penelitian terdiri dari data primer yaitu data yang diperoleh langsung oleh peneliti berupa hasil penilaian dari ahli dan hasil penilaian dari uji coba calon pengguna.

Teknik pengumpulan data yang digunakan yaitu: 1) metode angket merupakan kumpulan pertanyaan yang diajukan secara tertulis kepada subyek penelitian atau disebut responden dan cara menjawab pertanyaan adalan dengan cara tertulis pula, 2) metode dokumentasi merupakan pengumpulan data yang telah ada di sekolah yaitu berupa data prestasi belajar siswa.

Instrumen penelitian merupakan alat bantu dalam mengumpulkan data. Sesuai dengan teknik pengumpulan data terdapat instrument untuk pengumpulan angket dan studi dokumentasi. Angket yang digunakan untuk penilaian ahli mengacu pada pendapat yang diambil dari Department Pendidikan Nasional (Depdiknas, 2008:28) yang terdiri dari 4 komponen kelayakan yang kemudian dibagi menurut isi dan desain media nya. Instrumen calon pengguna menggunakan kuisioner yang dikembangkan oleh Arnold Lund dan rekan di Ameritech, U.S West Advance Technologies yang diberi nama USE Questionnaire. USE Questionnaire terdiri dari 4 aspek yaitu kegunaan, kemudahan dalam penggunaan, kemudahan dalam belajar dan kepuasan.

Teknik nalisis data menggunakan teknik analisis statistik deskriptif kuantitatif. Hasil penelitian yang terdapat dalam skala likert bernilai 4,3,2,1 kemudian di klasifikasikan menggunakan pembobotan yang diadaptasi dari (Mardapi, 2008: 123) sebagai berikut:

Tabel 1. Klasifikasi Skala Likert

\begin{tabular}{cc}
\hline Kriteria & Nilai Skor \\
\hline Sangat Layak & 4 \\
\hline Layak & 3 \\
\hline Tidak Layak & 2 \\
\hline Sangat Tidak Layak & 1
\end{tabular}

Hasil yang didapatkan akan dianalisis menggunakan rumus statistik sederhana yaitu sebagai berikut:

$$
\text { Kelayakan }=\frac{\text { total skor }}{\text { skor maksimum }} \times 100 \%
$$

Setelah dihitung persentase kelayakan, maka dapat ditransformasikan menjadi sebuah informasi yang dapat dibaca secara deskriptif dengan menentukan kriteria kualitatif sebagai berikut, yaitu a) menentukan persentase skor ideal (skor maksimum); b) menentukan persentase skor terendah (skor minimum); c) menentukan 
range; d) menentukan interval yang dikehendaki; dan e) menentukan lebar interval.

Berdasarkan tahap perhitungan tersebut didapatkan interpretasi kelayakan media pembelajaran untuk penilaian ahli materi ditunjukkan pada Tabel 2, ahli media pada Tabel 3 dan penilaian uji coba calon pengguna dapat dilihat pada Tabel 4, sebagai berikut:

Tabel2. Interpretasi Kelayakan Angket Ahli Materi

\begin{tabular}{llc}
\hline Persentase Pencapaian & $\begin{array}{c}\text { Skala } \\
\text { Nilai }\end{array}$ & Interpretasi \\
\hline $76 \% \leq$ skor $\leq 100 \%$ & $56-68$ & Sangat Layak \\
\hline $50 \% \leq$ skor $\leq 75 \%$ & $43-55$ & Layak \\
\hline $25 \% \leq$ skor $\leq 49 \%$ & $30-42$ & Tidak Layak \\
\hline $0 \% \leq$ skor $\leq 24 \%$ & $17-29$ & $\begin{array}{c}\text { Sangat Tidak } \\
\text { Layak }\end{array}$ \\
\hline
\end{tabular}

Tabel3. Interpretasi Kelayakan Angket Ahli Media

\begin{tabular}{lcc}
\hline \multicolumn{2}{l}{ Persentase PencapaianSkala Nilai } & Interpretasi \\
\hline $76 \% \leq$ skor $\leq 100 \%$ & $75,5-92$ & Sangat Layak \\
\hline $51 \% \leq$ skor $\leq 75 \%$ & $58-74,5$ & Layak \\
\hline $25 \% \leq$ skor $\leq 50 \%$ & $40,5-57$ & Tidak Layak \\
\hline $0 \% \leq$ skor $\leq 24 \%$ & $23-39,5$ & $\begin{array}{c}\text { Sangat Tidak } \\
\text { Layak }\end{array}$ \\
\hline
\end{tabular}

Tabel 4. Interpretasi Kelayakan Angket Calon Pengguna

\begin{tabular}{lcc}
\hline \multicolumn{2}{l}{ Persentase Pencapaian Skala Nilai } & Interpretasi \\
\hline $77 \% \leq$ skor $\leq 100 \%$ & $43-52$ & $\begin{array}{c}\text { Sangat } \\
\text { Layak }\end{array}$ \\
\hline $50 \% \leq$ skor $\leq 76 \%$ & $33-42$ & Layak \\
\hline $25 \% \leq$ skor $\leq 49 \%$ & $23-32$ & Tidak Layak \\
\hline $0 \% \leq$ skor $\leq 24 \%$ & $13-22$ & $\begin{array}{c}\text { Sangat } \\
\text { Tidak Layak }\end{array}$ \\
\hline
\end{tabular}

\section{HASIL DAN PEMBAHASAN}

Hasil penelitian ini terdiri dari hasil tahap pendefinisian (define), perancangan (design), pengembangan (develop), seperti yang ditetapkan sebelumnya.

Hasil tahap pendefinisian berupa: 1) analisis awal dimana siswa ditemukan permasalahan utama yaitu pemahaman atau kemampuan siswa untuk mengerti tentang bentuk struktur dalam bangunan nyata dan pemodelan struktur di awal materi belum maksimal dikarenakan kurangnya media pembelajaran yang dapat memvisualisasikan struktur dari nyata ke bidang gambar. 2) analisis siswa menghasilkan bentuk kecenderungan belajar siswa berupa gaya belajar yang secara umum terdiri dari visual, audio dan kinestetik, 3) analisis konsep menghasilkan tampilan umum penyajian materi. 4) analisis tugas menghasilkan kompetensi dasar dari Kurikulum 2013 revisi 2016 yang akan digunakan untuk media pembelajaran video animasi mekanika teknik, 5) perumusan tujuan pembelajaran yang dirumuskan berdasarkan analisis tugas sebelumnya.

Hasil tahap perancangan berupa pemilihan media yang akan digunakan yaitu Adobe Flash CS6 dan pemilihan format akhir media yaitu .exe (program) yang dapat dibuka langsung pada perangkat komputer.

Berdasarkan analisis deskriptif data angket yang diolah dengan menggunakan Microsoft Excel maka didapatkan hasil tahap pengembangan dari sisi materi pada Tabel 5 sebagai berikut:

Tabel 5. Hasil Penilaian Ahli Materi

\begin{tabular}{|c|c|c|c|c|}
\hline No & Aspek & Skor & Persentase & Kategori \\
\hline & $\begin{array}{l}\text { Sajian Materi } \\
\text { Pembelajaran }\end{array}$ & 28 & 100 & $\begin{array}{l}\text { Sangat } \\
\text { Layak }\end{array}$ \\
\hline 2 & Kelayakan Isi & 40 & 100 & $\begin{array}{l}\text { Sangat } \\
\text { Layak }\end{array}$ \\
\hline & ta-Rata & & 100 & $\begin{array}{l}\text { Sangat } \\
\text { Layak }\end{array}$ \\
\hline
\end{tabular}

Tabel 5 menunjukkan hasil penilaian ahli materi dan analisis data, di mana didapatkan skor 28 dari skor total maksimal 28 pada aspek Sajian Materi Pembelajaran dengan kategori sangat layak, dan skor 40 dari skor total maksimal 40 pada aspek kelayakan isi sehingga tergolong dalam kategori sangat layak. Untuk penilaian ahli media didapatkan hasil sebagai berikut:

Tabel 6. Hasil Penilaian Ahli Media 
Pengembangan Media Pembelajaran... (Tiara/ hal. 89-94)

\begin{tabular}{|c|c|c|c|c|c|}
\hline No & Aspek & Skor & Persentase & Kategori & aspek kepuasan dengan kategori \\
\hline 1 & $\begin{array}{l}\text { Sajian Materi } \\
\text { Pembelajaran }\end{array}$ & 18 & 90 & $\begin{array}{l}\text { Sangat } \\
\text { Layak }\end{array}$ & $\begin{array}{l}\text { Berdasarkan keempat aspek tersebut } \\
\text { didapatkan rata-rata persentase penilaian }\end{array}$ \\
\hline 2 & Kelayakan Isi & 15 & 93,8 & $\begin{array}{l}\text { Sangat } \\
\text { Layak }\end{array}$ & $\begin{array}{l}\text { dari calon pengguna adalah } 76,3 \% \text { dan } \\
\text { masuk kedalam kategori layak. }\end{array}$ \\
\hline & Desain Media & 51 & 91,1 & $\begin{array}{l}\text { Sangat } \\
\text { Layak }\end{array}$ & \\
\hline & ta-Rata & & 91,6 & $\begin{array}{l}\text { Sangat } \\
\text { Layak }\end{array}$ & \\
\hline
\end{tabular}

Pada Tabel 6 dapat dilihat hasil penilaian ahli media dan hasil analisis data berdasarkan penilaian yang telah dilakukan, di mana didapatkan skor 18 dari total skor maksimal 20 pada aspek sajian materi pembelajaran dengan kategori sangat layak, dan skor 15 dari total skor maksimal 16 untuk aspek kelayakan isi dengan kategori sangat layak, dan skor 51 total skor maksimal 56 pada aspek Desain Media dengan kategori sangat layak.

Berdasarkan uji coba pengembangan, di mana dilakukan penilaian oleh calon pengguna, dalam hal ini merupakan rata-rata penilaian dari dua orang guru pengampu mata pelajaran Mekanika Teknik didapatkan hasil sebagai berikut:

Tabel 7. Hasil Penilaian Calon Pengguna

\begin{tabular}{ccccc}
\hline No & Aspek & Skor & Persentase & Kategori \\
\hline 1 & Kegunaan & 10 & 83,35 & $\begin{array}{c}\text { Sangat } \\
\text { Layak }\end{array}$ \\
\hline 2 & $\begin{array}{l}\text { Kemudahan } \\
\text { dalam } \\
\text { Penggunaan }\end{array}$ & 11,5 & 71,88 & Layak \\
\hline 3 & $\begin{array}{l}\text { Kemudahan } \\
\text { dalam }\end{array}$ & 6 & 75 & Layak \\
& Belajar & & \\
\hline 4 & Kepuasan & 12 & 75 & Layak \\
\hline Rata-Rata & & 76,3 & Layak \\
\hline
\end{tabular}

Pada Tabel 7 dapat dilihat hasil penilaian calon pengguna dari hasil analisis data berdasarkan penilaian dari guru pengampu mata pelajaran Mekanika Teknik yang mendapatkan skor rata-rata 10 pada aspek Kegunaan dengan kategori sangat layak, skor 11,5 pada aspek kemudahan dalam penggunaan dengan kategori layak, skor 6 pada aspek Kemudahan dalam Belajar dengan kategori layak, dan skor 12 pada
Berdasarkan hasil analisis dan pembahasan penelitian ini maka dapat diambil kesimpulan, sebagai berikut: 1) Tahap pendefinisian terbagi menjadi lima tahapan yang menghasilkan analisis kebutuhan awal untuk dilakukan penelitian yaitu siswa belum mengetahui konsep dari pemodelan struktur, cara belajar setiap siswa yang berbeda dan media yang digunakan guru kurang bervariasi dengan metode pembelajaran guru masih konvensional. Analisis konsep berupa tampilan dan urutan menu secara umum. Analisis tugas menghasilkan kompetensi dasar yang dipilih menyesuaikan dengan kebutuhan siswa untuk mendapatkan visualisasi lebih nyata dari struktur nyata ke bidang gambar pada materi mekanika teknik, serta perumusan tujuan pembelajaran yang sesuai dengan analisis tugas; 2) Tahap perancangan perancangan atau desain media pembelajaran berisi gambaran materi dan perumusan template yang akan digunakan yaitu software adobe flash yaitu template action script 2.0. Template tersebut utamanya ditujukan untuk menghasilkan format media yang akan dioperasikan melalui komputer, laptop, atau notebook dalam format .exe.; dan 3) Tahap pengembangan atau develop terdiri dari dua tahap lagi yaitu penilaian oleh ahli (expert appraisal) dan uji coba pengembangan oleh calon pengguna. Berdasarkan dua tahap tersebut didapatkan skor dari ahli materi sebesar $100 \%$ dengan kategori sangat layak dan skor dari ahli media sebesar 91,6\% dengan kategori sangat layak. Selain dua hal tersebut juga didapatkan skor dari calon pengguna 76,3\% dengan kategori layak.

\section{DAFTAR RUJUKAN}


Departemen Pendidikan Nasional. (2008).

Panduan Pengembangan Bahan Ajar.

Jakarta: Direktorat Pendidikan

Nasional.

Lund, A. M. (2001). Measuring usability with the USE questionnaire. Usability $\begin{array}{llll}\text { Interface, } & 8 & \text { (2), } & 3-6\end{array}$ (www.stcsig.org/usability/newsletter/i ndex.html).

Mardapi, Djemari. (2008). Teknik Penyusunan Instrumen Tes dan NonTes. Yogyakarta: Mitra Cendekia Press.

Peraturan Pemerintah Republik Indonesia Nomor 29 Tahun 1990. Pendidikan Menengah. 10 Juli 1990. Jakarta.

Sukoco, Arifin, Z., Sutiman, \& Wakid, M. (2014). Pengembangan Media Pembelajaran Interaktif Berbasis Komputer Untuk Peserta Didik Mata Pelajaran Teknik Kendaraan Ringan. Jurnal Pendidikan Teknologi dan Kejuruan, 22, 215-226.

Supriyadi. (2016). Adobe Flash Untuk Mendukung Pembelajaran. Jurnal Komunikasi, 7, 38-42.

Undang-Undang Republik Indonesia Nomor 20 Tahun 2003. Sistem Pendidikan Nasional. 8 Juli 2003. Lembaran Negara Republik Indonesia Tahun 2003 Nomor 4301. Jakarta.

Widiana, I.W., Jampel, N.I., \& Prawini, P,I. (2018). The Effectiveness Of Traditional Game-Based Communication Learning Activity For Cognitive Process Dimension Learning Achievement. Jurnal Cakrawala Pendidikan, 37, 260-269. 